\title{
INFLUENCE OF THE CALCIUM ON MICROBIAL STABILITY AND TEXTURE OF OSMOTIC DEHYDRATED PINEAPPLE SLICES.
}

\author{
E.J.C.N. Karunarathna ${ }^{1}$ and R.M.U.S.K. Rathnayaka ${ }^{1}$
}

\begin{abstract}
The aim of this study was to analyze the effect of calcium on microbial stability and texture of osmotic dehydrated pineapple slices in the preparation of minimally processed pineapple slices by osmotic dehydration in atmospheric conditions. Pineapple slices of $10 \mathrm{~mm}$ thickness were treated with osmotic agents consisting of glucose solutions of $50^{\circ}$ brix incorporated with 0,1 , and $2 \%$ calcium lactate, until they reached $30^{\circ}$ and $40^{\circ}$ brix at room temperature. The effect of osmotic dehydration on mechanical properties and microbial stability of pineapple slices were analyzed throughout storage at $10{ }^{\circ} \mathrm{C}$ for 28 days. Moisture content was determined using the standard method. Mechanical properties were analyzed using a penetrometer, and microbial analysis was done according to the standard microbial tests. Compared to fresh cuts and control samples, samples treated with osmotic agents containing $2 \%$ calcium lactate showed a significantly lower growth of mesophilic bacteria, yeast and moulds. Furthermore, the samples treated with calcium lactate had a better firmness compared to those without treatment. Out of all sample tested, $30^{\circ}$ brix sample with $2 \%$ calcium lactate and $40^{\circ}$ brix sample with $1 \%$ calcium lactate were identified as the better samples with good firmness and low microbial growth. Treatment of pineapple using dehydration solutions with calcium lactate has been found useful in producing osmotic dehydrated pineapple slices characterized with good firmness, high microbial stability and high keeping quality.
\end{abstract}

Key words: Osmotic dehydration, Pineapple, calcium lactate

\section{INTRODUCTION}

Osmotic dehydration is a useful technique for the concentration of fruit and vegetables by placing them, as whole or in pieces, in sugars or salts aqueous solutions of high osmotic pressure. Partially dehydrated fruits and vegetables by this method can be added to foods such as desserts, yogurt, icecrams, confectionary, and bakery products. After additional drying by heat treatments, those partially dehydrated products can also be used as components of cereals or snacks of direct consumption (Lenart, 1996; Torreggiani et al. 2001). Osmotic dehydration is effective at ambient temperature, so heat damage to texture, colour and flavour can be minimized (Torrengiani, 1993). It has low influence on mineral content and vitamin losses, and hence osmotically

\footnotetext{
${ }^{1}$ Department of Food Science and Technology, Faculty of Applied Sciences, Sabaragamuwa University of Sri Lanka, P.O. Box 02, Belihuloya Sri Lanka
} 
The Journal of Agricultural Science, 2012 vol. 7, no 1

dehydrated fruits have a good retention of flavour, aroma and nutritional content (Barbosa et al., 1996). It helps to prevent food from enzymatic and non-enzymatic browning and to stabilize the fruit colour (Moreno et al., 2005, Pereira et al., 2006, Chottanom et al., 2011). At the same time, it helps to prevent from the volatile flavorings Compound losses Chattanom et al., 2011) and to improve the texture and flavor of the food (Bidaisee et al., 2001, Raoult, 1994). Osmotic dehydration reduces the water activity of the food and makes an unfavorable environment for the microbial growth (Alzamora et al., 1995). Due to these reasons, minimally processed fruits obtained by osmotic dehydration treatments are with a longer shelf life, sensorial characteristics similar to the fresh fruits and with a higher nutritive value (Fito $e t$ al., 2000). In addition, osmotic dehydration is acknowledge to be an energy efficient method compared to drying and freezing since there is no need for a phase change in this method (Chottanom et al., 2011). Although, during the osmotic dehydration process water soluble substances such as saccharides, organic acids, vitamins etc. can be removed from the fruit, that loss is not significantly effect on its nutritional and organoleptic properties (Lenart 1996).

In the osmotic dehydration two major simultaneous counter-current flows can be observed; a significant water flow from the food to the solution and flow of solute from the solution to the food. These flows caused to increase the cellular concentration of the food due to water loss and hence to alter of cell membrane. Furthermore, this causes to volume reduction of cell and separation from the cell wall due to mechanical stress on the middle lamella which are also altered (Alzamora et al., 2000). To overcome this problem, calcium can be used as a texturing agent which can maintain the firmness of the food by cross linking with cell wall and middle lamella pectin (Quales et al., 2004, Grant et al., 1973). Calcium chloride, calcium hydroxide, and calcium lactate can be used as calcium source and firming agent.

The aim of this research was to determine the feasibility of obtaining osmotically dehydrated pineapple slices with longer shelf life and to test the ability of calcium lactate to maintain the firmness of pineapple slices during and after the osmotic dehydration.

\section{MATERIALS AND METHODS}

Fresh pineapples (Ver. Cayenne), with firm texture and about $95 \%$ maturity, were purchased from local market, thouraly washed with water to remove adhering soil and other debris. Then they were peeled manually using a knife. The eyes and the center cork of the peeled pineapple were removed and cut in to slices of $10 \mathrm{~mm}$ thick. The average moisture content of fresh cut was found to be $13.33 \%$ on a wet basis. Glucose the osmotic agent, was purchased from a local super market. The osmotic solutions were prepared by mixing the glucose with proper amount of distiled water. 
E.J.C.N. Karunarathna and R.M.U.S.K. Rathnayaka

\section{Osmotic treatment}

The osmotic dehydration was conducted in a $500 \mathrm{~mL}$ Erlenmeyer flask, which is placed in a thermostatically controlled water bath shaker at atmospheric pressure to lead sample solid concentration to 30 brix and $40^{\circ}$ brix, separately. Glucose solutions of $50^{\circ}$ brix with 0,1 , and $2 \%$ of calcium lactate (Analytical grade) were used as osmotic agents. The dehydration was carried out at fruit to solution ratio of 1:2. Osmotically dehydrated pineapple slices were stored at $10^{\circ} \mathrm{C}$ in polythene covers and used for the analysis of mechanical properties and microbial stability.

\section{Analysis of sample composition}

Moisture content of all the tested samples was determined by drying to constant weight at $105^{\circ} \mathrm{C}$ in an oven for 4 hours (Ranganna, 1986). Soluble solids of the samples were measured by a Refractometer (Erma, Japan, brix range 0 - 62) in triplicate (Adaption of method 934.06 AOAC, 2000). All samples were weighted before and after treatment to determine mass change, and water loss, referred per mass percentage of initial sample. Then, percentage water loss of the final products $\left(\mathrm{W}_{\mathrm{x}}\right)$, mass loss $\left(\mathrm{M}_{\mathrm{x}}\right)$ and solid gain $\left(S_{\mathrm{x}}\right)$ were evaluated for all tested samples using the following equations.

$$
\begin{aligned}
& \mathrm{W}_{\mathrm{x}}=\frac{\left(\mathrm{W}_{\mathrm{im}}-\mathrm{W}_{\mathrm{fm}}\right)}{\left(\mathrm{W}_{\mathrm{im}}\right)} \times 100 \\
& \mathrm{M}_{\mathrm{x}}=\frac{\left(\mathrm{M}_{1}-\mathrm{M}_{2}\right)}{\left(\mathrm{M}_{1}\right)} \times 100
\end{aligned}
$$

$S_{\mathrm{x}}=\mathrm{S}_{2}-\mathrm{S}_{1}$

$\mathrm{W}_{\mathrm{x}}=$ Water loss of samples

$\mathrm{W}_{\mathrm{im}}=$ Initial moisture content $(\%$ wet basis)

$\mathrm{W}_{\mathrm{fm}}=$ Final moisture content $(\%$ wet basis)

$\mathrm{M}_{\mathrm{x}}=$ Mass loss during osmosis

$\mathrm{M}_{1}=$ Mass before osmosis

$\mathrm{M}_{2}=$ Mass after osmosis

$\mathrm{S}_{\mathrm{X}}=$ Solid content $\%$

$\mathrm{S}_{1}=$ Initial solid content $\%$

$\mathrm{S}_{2}=$ Final solid content $\%$

\section{Determination of moisture loss variation of samples with time}

To study the effect of calcium lactate on the moisture loss of osmotically dehydrated samples, three samples added with 0,1 , and $2 \%$ of calcium lactate of $30^{\circ}$ brix was dehydrated in a oven at $105{ }^{\circ} \mathrm{C}$ and moisture loss was measured in 30 minutes intervals until reach a constant weight.

\section{Measurements of mechanical properties}

Mechanical properties were analyzed using a Penetrometer (Model AFT 0235, Germany) by means of puncture test (Adaption of method 934.06 AOAC, 2000). Three replicates were performed for each treatment to measure the texture and three locations 
The Journal of Agricultural Science, 2012 vol. 7, no 1

of each replicate were punctured to obtain the texture readings.

\section{Microbial Analysis}

Microbial tests were carried out in three replicates for each treatements. One gram of each treated samples was mixed in $9 \mathrm{~mL}$ of ringer solution and used to prepare serial dilutions for microbial analysis. Mesophilic aerobic populations were analyzed in Plate Count Agar as described by Casetello et al., 2009 and samples were incubated at $31^{\circ} \mathrm{C}$ for 2 days. Yeast and moulds were determined by using Potato Dextrose Agar as medium at $31^{\circ} \mathrm{C}$ for 5 days. Microbial analysis were carried out on days 0 (processing day) , 3, 7, 16, and 28. Number of colonies between 30-300 for total plate count and between 0-30 for yeast and moulds were counted after incubation.

\section{RESULTS AND DISCUSSION}

\section{Effect of Calcium Chloride on osmotic dehydration process}

Time required obtaining pre-decided brix values of $30^{\circ}$ and $40^{\circ}$ using osmotic dehydration solutions added with different concentrations of calcium lactate were evaluated. Addition of calcium lactate shown significant effect on the time required to attain the predecided brix values. More time was needed when calcium lactate was added to the solution. When calcium lactate concentration was increased the time required to reach brix values was also increased (Table 1). These results indicate that the interaction between calcium and cellular matrix causing reduction of the water diffusion efficiency, as reported by other authors for other fruit and vegetables (Barrera $e t$ al., 2004, Castello et al., 2009). This reduction of water diffusion efficiency is due to calcium cross linking effect in the cellular matrix which affects the water permeability of the cell structures, and influence of calcium ion on the active water transport through cell membrane (Johansson et al., 1996, Tyerman et al., 1999).

\section{Compositional changes}

Changes in compositional characteristics during and after osmotic dehydration process play an important role in obtaining good quality dehydrated product. Several investigations have been carried on these changes using different types of fruits and vegitables, and have shown that the dehydration process can be modled based on these changes (Manivannan et al., 2008, Aniko et al., 2002, Alam et al., 2010, Ruiz et al., 2010). Mass loss, solute gain and water loss are important parameters studied under compositional changes. In this study, percentage water loss of the final products $\left(\mathrm{W}_{\mathrm{x}}\right)$, mass loss $\left(\mathrm{M}_{\mathrm{x}}\right)$ and Solid gain $\left(S_{\mathrm{x}}\right)$ were evaluated for osmotically dehydrated samples with different tratements. Data obtained are shown in the Table 01.

As shown in the Table 01, the time taken to reach $40^{\circ}$ brix value were higher that of $30^{\circ}$ brix. Time taken to reach the brix value 30 was increased when the calcium percentage was increased in all tested $30^{\circ}$ brix samples. Similar results were obtained for the 
E.J.C.N. Karunarathna and R.M.U.S.K. Rathnayaka

Table 1: Compositional changes of treated pineapple slices

\begin{tabular}{ccccc}
\hline Treatment & $\begin{array}{c}\text { Time } \\
(\text { min) }\end{array}$ & $\begin{array}{c}\text { \% Solid } \\
\text { gain }\end{array}$ & $\begin{array}{c}\text { \% Water loss } \\
\text { (final product) }\end{array}$ & $\begin{array}{c}\text { \% Mass } \\
\text { loss }\end{array}$ \\
\hline OD 30 brix & 15 & 7.56 & -56.99 & -28.21 \\
OD 30 brix 1\% $\mathrm{CaCl}_{2}$ & 22 & 8.31 & -62.49 & -26.22 \\
OD 30 brix 2\% $\mathrm{CaCl}_{2}$ & 30 & 4.56 & -34.35 & -23.84 \\
OD 40 brix & 115 & 9.51 & -71.49 & -10.38 \\
OD 40 brix 1\% $\mathrm{CaCl}_{2}$ & 127 & 9.89 & -74.41 & -8.48 \\
OD 40 brix 2\% $\mathrm{CaCl}_{2}$ & 148 & 7.09 & -53.33 & -7.33 \\
\hline
\end{tabular}

Table 2: Changes in mechanical properties

\begin{tabular}{lccc}
\hline Sample & Median & Average rank & Z value \\
& & & \\
\hline Fresh cut & 0.5500 & 5.8 & -3.40 \\
$30^{\circ} \mathrm{Brix} 0 \% \mathrm{Ca}$ & 0.7000 & 11.0 & -2.26 \\
$30^{\circ} \mathrm{Brix} 1 \% \mathrm{Ca}$ & 0.9000 & 21.8 & 0.05 \\
$30^{\circ} \mathrm{Brix} 2 \% \mathrm{Ca}$ & 1.1500 & 29.3 & 1.67 \\
$40^{\circ} \mathrm{Brix} 0 \% \mathrm{Ca}$ & 1.0500 & 30.0 & 1.83 \\
$40^{\circ} \mathrm{Brix} 1 \% \mathrm{Ca}$ & 1.1500 & 31.1 & 2.07 \\
$40^{\circ} \mathrm{Brix} 2 \% \mathrm{Ca}$ & 1.0500 & 21.7 & 0.04 \\
\hline
\end{tabular}

different treatments of $40^{\circ}$ brix samples. These results indicate the influence of calcium on the osmotic dehydration process. As explained by other authors for different kinds of fruits (Monsalve et al., 1993; Luna et al., 1999; Mastrangelo et al., 2000), the firming effect caused by calcium salts could attribute to the formation of linkages between calcium ions and pectin present in the middle lamella and cell wall. Confirming the effect of calcium salt of osmotic dehydration process, solid gain percentage was decreased while calcium salt percentage was increased.
The mass loss of pineapple slices osmotically dehydrated to $30^{\circ}$ brix was determined. There was a lower mass loss in osmotically dehydrated pineapple slices using dehydration solution added with $2 \%$ calcium compared to the dehydrated pineapple slices using $1 \%$ calcium and control solution.

This result indicates that calcium enables building the cross linking effect in the cellular matrix which in turn affects the water permeability of cell structure and influence the active water 
The Journal of Agricultural Science, 2012 vol. 7, no 1

transport through the cell membrane as explained by Johansson et al., (1996) and Tyerman et al., (1999).

Table 02 shows the median values, Average rank and $\mathrm{Z}$ values of texture readings of samples obtained from the puncture test and it indicates the differences of textural properties of osmotic dehydrated samples. According to the results obtained from Kruscal Wallies test, there is a significant difference between osmotic dehydrated samples at 5\% levels with regard to texture $(\mathrm{P}=0.001)$. Texture of the osmatically dehydrated samples using calcium salt showed better texture compared to other samples indicating the ability of calcium salt to keep the firmness of final products of osmotic dehydration.

\section{The effect of osmotic dehydration and calcium incorporation on microbiological stability of the product} Microbial load and diversity in a food item are major concerns in the food industry. As per the recommended microbiological standards for fruits and vegetables, the maximum limits for mesophilic aerobics and yeast and molds are as $10^{4} \mathrm{CFU} / \mathrm{g}$ and $10^{2} \mathrm{CFU} / \mathrm{g}$ respectively (Casetello et al., 2009). However, as far as the pathogenic microorganisms are concerned, allowable microbial number in a gram of food is very low or zero. In the present study microbial stability of osmatically dehydrated pineapple slices were evaluated. Effect of calcium on microbiological stability was also studied. Microbial counts of mesophilic bacteria and yeast and molds were taken for fresh cut pineapple slices and osmotically dehydrated pineapple slices with and without calcium lactate throughout the storage of 28 days. The data obtained are shown in the Figure 01 and 02 .

As shown in the two figures (Figure 01 and 02), microbial count of fresh cuts were higher than those of osmotically dehydrated samples. This indicates that the osmotic dehydration can be used to improve microbial stability. This is an expected consequence because the water activity of food is reduced by osmotic dehydration. Furthermore, as shown in figures, the microbial counts of the osmotically dehydrated samples using calcium containing solutions were lower than the others. In addition to that, higher reduction of microbial counts was observed when the calcium concentration was increased. This is because Calcium imparts cell membrane of pineapple slices the firmness and then the cell membrane acts as a barrier for microorganisms to penetrate. These results confirmed the ability to use calcium as a firming agent in osmotic dehydration of pineapple slices as reported by other authors for other fruits and vegetables namely Abbutt et al., (1989) and Castello et al., (2009) for Apple, Lunna et al., (2000) for Cantaloupe melon, Torres et al., (2008) for Mango. As the results indicated, calcium containing osmotic dehydration solutions can be used to reduce the microbial growth and thereby to increase the shelf life of minimally processed pineapple slices obtained by osmotic dehydration. 


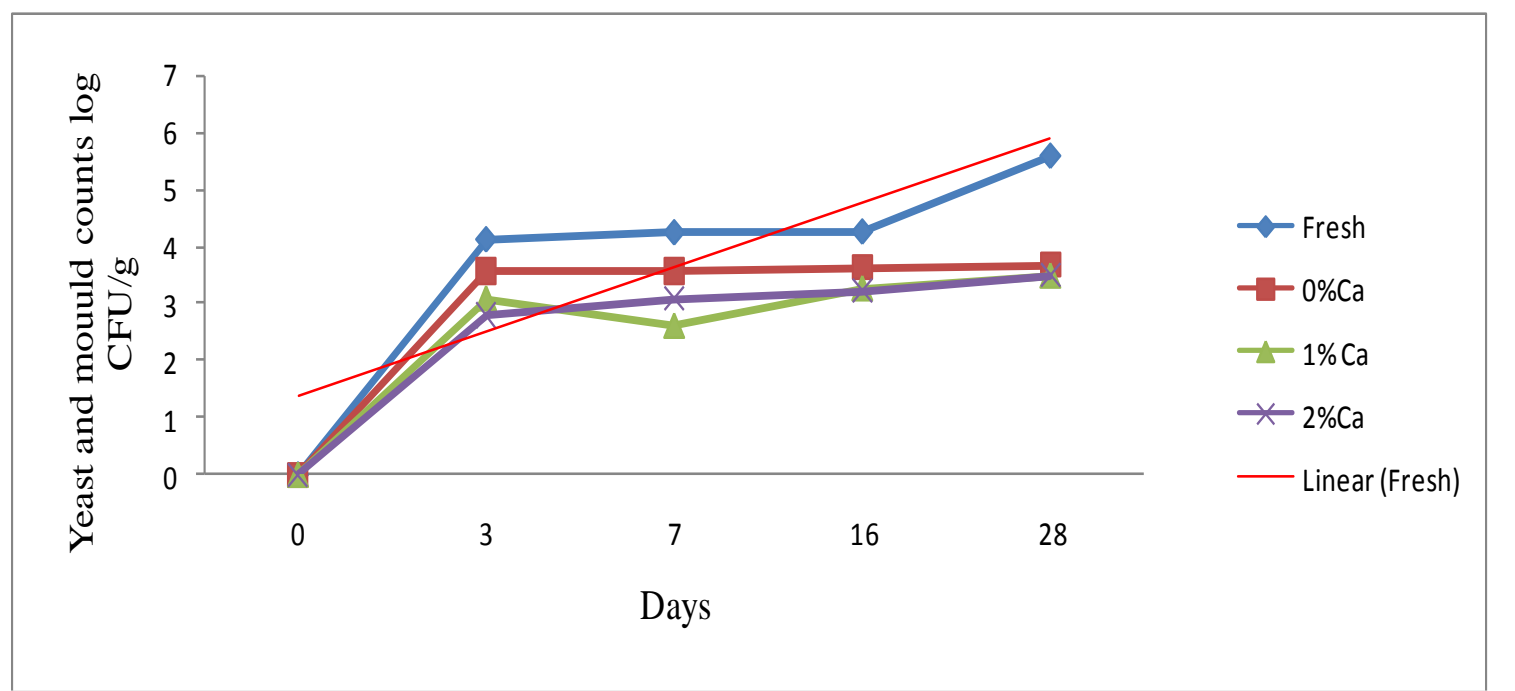

Figure 01: Variation of yeast and mould count in $30^{\circ}$ brix osmotic dehydrated samples

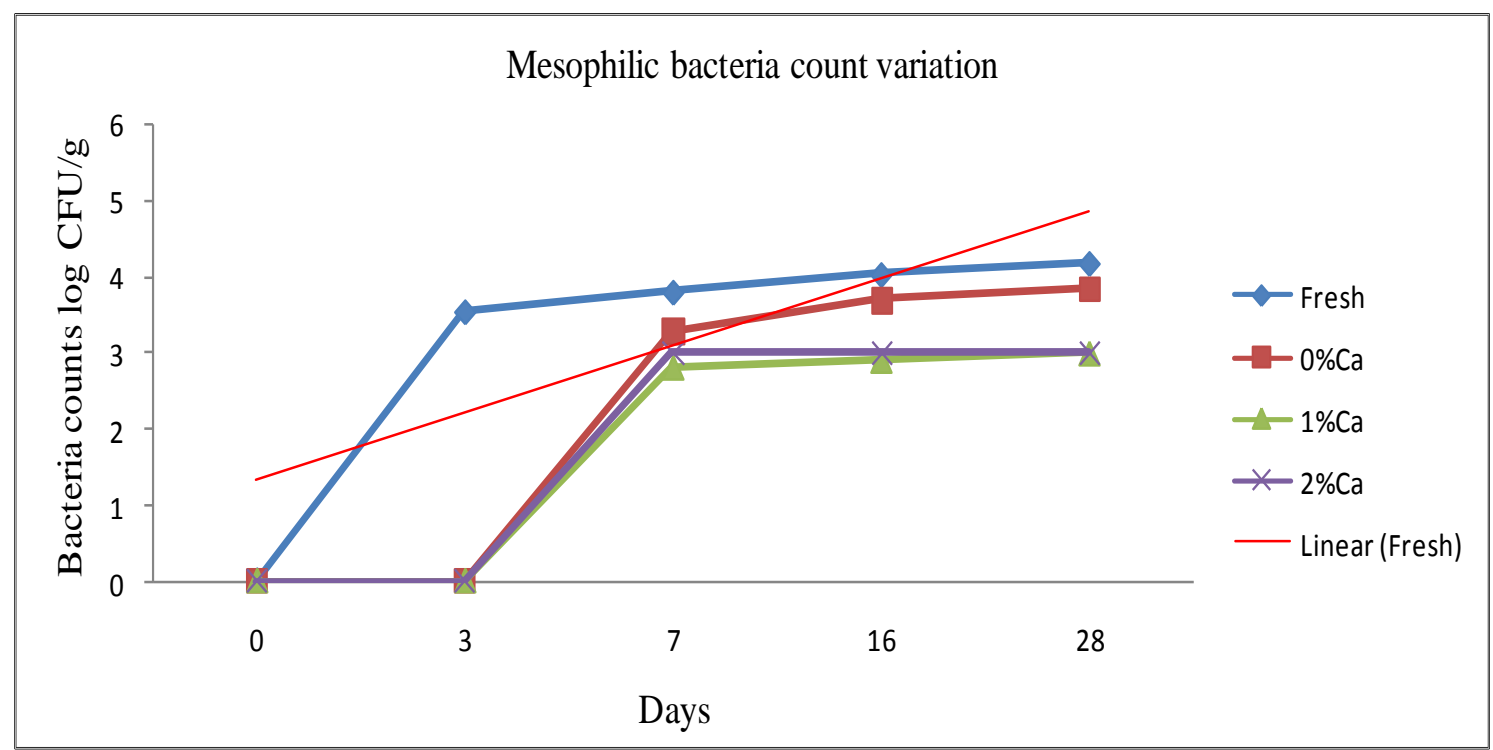

Figure 02: Variation of bacterial counts in $30^{\circ}$ brix osmotic dehydrated samples.

\section{CONCLUSIONS}

According to the present study, calcium has been identified as an effective firming agent in the osmotic dehydration of pineapple slices. When calcium is used as a component of osmotic solution, microbial stability, mechanical properties, and physicochemical properties of osmotic dehydrated pineapple slices can be increased. 
The Journal of Agricultural Science, 2012 vol. 7, no 1

\section{REFERENCES}

Abbott, J.A., Conway, W.S. and Sams, C.E. (1989). Post harvest calcium chloride infiltration affect textural attributes of apples. Journal of the American Society for Horticultural Sciences, 114, 932-936.

Alam, M.S. and Singh, A. (2010). Optimization of Osmotic Dehydration Process of Aonla Fruit in Salt Solution. International Journal of Food Engineering, Volume 6, Issue 1: 1-22.

Alzamora, S.M., Castro, M.A., Vidales. S.i., Nieto, A.B. and Salvatori, D. (2000). The rple of tissue microstructure in the textural characteristics of minimally processed fruits.In: Alzomora S.M., Tapia, M.S., Lopez-Malo, A. (Eds.), In minimally processed fruits and vegetables fundamental aspects and applications. Aspen publishers Inc., Maryland, pp. 153-172 (Chapter 9).

Alzamora, S.M., Gerschenson, L.N. and Campos, C.A. (1995). Sorbic acid stability in meat products of reduced water activity. Meat Science, 41 (1), 37-46.

Aniko, M., and Peter, M. (2002). Modeling of sugar transfer during osmotic dehydration of carrots. Periodica Polytechnica Ser. Chem. Eng. vol. 46, No. 12, PP. 83-92.

AOAC, (2000). Official methods of analysis of AOAC International, $17^{\text {th }}$ edition Gaithersburg, MD, USA.

Barbosa, C. G.V. and Vega, M. H. (1996). Dehydration of Foods. New York, NY: Chapman \& Hall.

Barrera, C., Betoret, N. and Fito, P. (2004). $\mathrm{Ca}^{+2}$ and $\mathrm{Fe}^{+2}$ Influence on the Osmotic dehydration Kinetics of Apple slice (Var Granny Smith). Journel of Food InEngineering, 65, 9-14.

Bidaisee, G., and Badrie, N. (2001). Osmotic dehydration of cashew apples (Anacardium occidentale L.): Quality evaluation of candied cashew apples. International Journal of Food Science and Technology, 36, 71-78.

Castello, M.L., Igual, M., Fito, P.J. and Chiralt A. (2009). Influence of osmotic dehydration on texture, respiration and microbial stability of apple slices (Var. Granny Smith). Journal of Food Engineering, 91, 1-9.

Chottanom, P. and Srisa, A. M. (2011). Osmotic dehydration as a factor in freezing of tomato. Amarican Journal of food technology, 6 (6) : 483-491.

Fito. and Chiralt, A., (2000). Vaccum impregnation of plant tissue. In: Alzamora, S.m., Tapia, M.S., Lopez-Malo (Eds), A design of minimal processing technologies for fruit and vegetables. Aspen Publishers Inc., Maryland, pp.189-204.

Grant, G.T., Morris, E.R., Rees, D.A., Smith, P.J.C. and Thom, D. (1973). Biologycal interactions between polysaccharides and divalent cations: the egg-box model.Febs Lett 32, 195-198.

Johansson, I., Larsson, C., Ek, B. and Kjellbom, P. (1996). The major intregal proteins of Spinach leaf plasma membranes are putative aquaporinns and are phosphorilated in response to $\mathrm{Ca}^{+2}$ and apoplastic water potential. The Plant cell, 8, 1181-1191. 
E.J.C.N. Karunarathna and R.M.U.S.K. Rathnayaka

Lenart, A. (1996). Osmo-convective drying of fruits and vegetables: Technology and application. Drying Technology 14(2): 391-413.

Luna, G. I. and Barrett, D.M. (2000). Comparison of calcium chloride and calcium lactate effectiveness in maintaining shelf stability and quality of fresh-cut cantaloupes. Postharvest Biology and Technology, 19, 61-72.

Luna, G. I., Cantwell, M. and Barrett, D.M. (1999). Fresh-cut cantaloupe: effects of $\mathrm{CaCl}_{2}$ dips and heat treatments on firmness and metabolic activity. Post harvest Biology and Technology, 17 (3), 201-213.

Manivannan, P. and Rajasimman. M. (2008). Osmotic Dehydration of Beetroot in Salt Solution: Optimization of Parameters through Statistical Experimental Design. International Journal of Chemical and Biological Engineering, 1:4: 214-221.

Mastrangelo, M. M., Rojas, A. M., Castro, M. A., Gerschenson, L. N. and Alzamora, S. M. (2000). Texture and Structure of Glucose-Infused Melon. J. Sci. Food Agric., 80, 769 .

Monsalve, G. A., Barbosa, C. G. V. and Cavalieri, R. P. (1993). Mass Transfer and Textural Changes During processing of Apples by Combined Methods. Journal of Food Science, 58, 11-18.

Moreno, C. E. J., Gonzalez, G. R., Grajales, L. A., Ruiz, C. M. A. and Abud, A. M. (2005). Water diffusivity and colour of cactus pear fruits (Opuntia ficus indica) subjected to osmotic dehydration. International Journal of Food Properties, 8, 323-336.

Pereira, L. M., Ferrari, C. C., Mastrantonio, S. D. S., Rodrigues, A. C. C. and Hubinger, M. D. (2006). Kinetic aspects, texture, and colour evaluation of some tropical fruits during osmotic dehydration. Drying Technology, 24, 475-484.

Quiles, A., Hernando, I.M., Perez. M. I., Llorca, E., Larrea, V. and Lluch, M. A. (2004). The effect of Parenchyma of Osmotic dehydrated "Granny Smith" apple. Journel of Science Food and Agriculture, 84, 1765-1770.

Ranganna, S. (1986), Analysis and quality control for Fruit and vegetable products, $2^{\text {nd }}$ edition, CBS publications, India, 420p.

Raoult, W. A. L. (1994). Advances in osmotic dehydration. Trends in Food Science Technology, vol.5, pp. 255-260.

Ruiz, L. I. I., Castillo, Z. R. I., Salgado, C. M. A., Rodriguez, J. G. C. and Garcia, A. M. A. (2010). Mass Transfer Modeling During Osmotic Dehydration of Hexahedral Pineapple Slices in Limited Volume Solutions. Food Bioprocess Technology, 3:427-433.

Torreggiani, D. and Bertolo, G. (2001). Osmotic pre-treatments in fruit processing: chemical, physical and structural effects. Journal of Food Engineering, 49, 247253.

Torrengiani D. (1993). Osmotic dehydration in fruits and vegetable processing. Food Research International, vol. 26, 1993, pp. 59 - 68.

Torres, J.D., Castello, M.L., Escriche, I. and Chiralt, A. (2008). Quality characteristics, respiration rates and microbial stability of osmotically treated Mango tissue 
The Journal of Agricultural Science, 2012 vol. 7, no 1

(Mangifera indica L.) with or without calcium lactate. Food Science and Technology International, 14: 355-365.

Tyerman, S.D., Bohnert, H.J., Maurel, C., Steudle, E. and Smith, J.A.C. (1999). Plant aquaporins, their molecular biology, biophysics and significance for plant water relations. Journal of Experimental Botany, 50, 1055-1071. 